\title{
Transformation Of Blood Learning Through Applications And Teaching Effectiveness Of Students In The 2019 Corona Virus Disease Pandemic Period (Covid-19)
}

\author{
${ }^{1}$ Jessy Parmawati Atmaja, ${ }^{2}$ Rostati \\ ${ }^{12}$ Lecturer at STKIP Harapan Bima
}

\begin{abstract}
The 2019 corona virus disease (Covid-19) outbreak which has hit the world, presents its own challenges for educational institutions, especially elementary schools. Through the Ministry of Education and Culture, the Government has prohibited educational institutions from implementing face-to-face (conventional) learning and ordered to organize online learning. The implementation of this system automatically encourages education actors to be ready for implementation, even though so far several schools have never conducted learning with an online system. Through this research, the researcher wants to analyze how effective the learning system is from the point of view of the educator. The sample of this research is teaching staff at the elementary school level. The instrument used was a questionnaire distributed online using the ms.form link. Online learning that is not properly prepared will have an impact on the effectiveness of teaching by educators, as well as the acceptance of students for online learning because of the very diverse abilities of acceptance of the material and delivery of educators.
\end{abstract}

\section{Keywords: Online Learning, Covid-19, Teaching Effectiveness}

Abstrak. Wabah corona virus disease 2019 (Covid-19) yang telah melanda dunia, memberikan tantangan tersendiri bagi lembaga pendidikan, khususnya sekolah dasar. Melalui Kementerian Pendidikan dan Kebudayaan Pemerintah telah melarang lembaga pendidikan untuk melaksanakan pembelajaran tatap muka (konvensional) dan memerintahkan untuk menyelenggarakan pembelajaran secara daring. Pemberlakuan sistem ini otomatis mendorong pelaku pendidikan untuk siap dalam pelaksanaannya, meskipun selama ini beberapa sekolah belum pernah melakukan pembelajaran dengan sistem daring. Melalui penelitian ini, peneliti ingin menganalisis seberapa efektif pelaksanaan sistem pembelajaran dari sudut pandang tenaga pendidik. Sampel penelitian ini adalah tenaga pendidik yang mengajar di tingkat sekolah dasar. Instrumen yang digunakan adalah angket yang disebarkan secara daring menggunakan link ms.form. Pembelajaran daring yang tidak dipersiapkan secara matang akan berdampak terhadap efektifitas pengajaran oleh para tenaga pendidik, demikian pula penerimaan peserta didik atas pembelajaran daring karena kemampuan penerimaan yang sangat beragam terhadap materi dan penyampaian tenaga pendidik.

\section{Kata Kunci: Pembelajaran Daring, Covid-19, Efektifitas Pengajaran}

\section{PENDAHULUAN}

Pandemi covid-19 yang melanda berdampak pada perubahan tatanan kehidupan masyarakat dunia. Berbagai negara telah menerapkan social distancing (pembatasan jarak sosial) yang dirancang untuk mengurangi interaksi antara orang-orang dalam komunitas yang lebih luas. Hal ini membawa dampak besar bagi seluruh sektor dalam kehidupan salah satunya pendidikan. Aktifitas belajar mengajar dari pembelajaran tatap muka menjadi pembelajaran daring (online learning). Kita harus jujur bahwa proses adaptasi pembelajaran dari pembelajaran tatap muka ke pembelajaran daring tidaklah mudah namun harus menjadi pilihan sulit ditengah situasi pandemi yang tidak menentu. 
Sistem pembelajaran yang sangat berubah ini membawa dampak besar dalam dunia pendidikan. Salah satu penyebab dari perubahan besar ini adalah dikarenakan pembelajaran daring ini diberlakukan secara tiba-tiba, hal ini berakibat besar pada kesiapan sekolah, tenaga pendidik dan peserta didik dalam melaksanakan pembelajaran.

Pembelajaran daring yang tidak dipersiapkan secara matang akan berdampak terhadap efektifitas pengajaran oleh para tenaga pendidik, demikian pula penerimaan peserta didik atas pembelajaran daring karena kemampuan penerimaan yang sangat beragam terhadap materi dan penyampaian tenaga pendidik.

Budaya pelaku pendidikan yang biasanya beraktifitas disekolah seketika berubah melakukan aktifitas pembelajaran dirumah secara daring tentu membutuhkan adaptasi yang tidak sebentar, ditambah lagi dengan tidak sedikitnya sekolah didesa-desa yang tidak memiliki fasilitas penunjang berupa tekhnologi terpadu guna mendukung proses pembelajaran daring membuat proses pembelajaran berjalan tidak sesuai dengan tujuan.

\section{METODE PENELITIAN}

Penelitian ini merupakan penelitian deskriptif kualitatif dengan menggunakan metode survey. Menurut Sugiyono (2013:12) pengertian metode survey adalah :

"Penelitian yang dilakukan dengan menggunakan angket sebagai alat penelitian yang dilakukan pada populasi besar maupun kecil, tetapi data yang dipelajari adalah data dari sampel yang diambil dari populasi tersebut, sehingga ditemukan kejadian relatif, distribusi, dan hubungan antar variabel, sosiologis maupun psikologis".

Metode survey yang dilakukan secara daring. Pengambilan data dilakukan dengan metode sampel jenuh, dimana populasi yang ada seluruhnya dijadikan sampel. Pengumpulan data dilakukan dengan menyebarkan angket secara daring kepada 27 orang tenaga pendidik di SDN 9 Sila Kecamatan Bolo Kabupaten Bima sebagai sampel yang terdiri dari 9 orang laki-laki dan
18 orang perempuan yang melakukan pembelajaran daring. Pengumpulan data menggunakan angket digunakan untuk mendapatkan tanggapan dari tenaga pendidik selaku responden. Instrumen penelitian yang digunakan peneliti terdiri atas 4 kategori yang dikembangkan menjadi 14 pernyataan. Adapapun rincian instrumen yang digunakan antara lain:

Tabel: Instrumen Penelitian



Keterangan:

$\begin{array}{ll}\text { SS } & \text { : Sangat Setuju } \\ \text { S } & \text { : Setuju } \\ \text { TS } & \text { : Tidak Setuju } \\ \text { STS } & \text { : Sangat Tidak Setuju } \\ \text { RR } & \text { : Ragu-ragu }\end{array}$

Analisis data penelitian dilakukan menggunakan model analisis Miles \& Huberman (1994) yang terdiri dari tiga tahapan, yaitu reduksi data, display data, serta penarikan dan verifikasi kesimpulan.

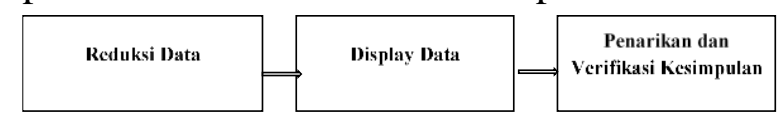

Gambar: Tahapan Analisis data penelitian

Analisis data penelitian tahap reduksi data merupakan tahap mengumpulkan seluruh 
informasi yang dibutuhkan dari hasil angket lalu di kelompokkan datanya. Tahap display data merupakan pemaparan data yang diperlukan dalam penelitian dan yang tidak perlu dibuang. Tahap penarikan dan verifikasi kesimpulan adalah tahap interpretasi data penelitian untuk ditarik kesimpulan berdasarkan fenomena yang didapatkan (Miles, M. B., \& Huberman, M.,1994).

\section{PEMBAHASAN}

Tenaga pendidik memilih beberapa aplikasi sebagai media pembelajaran untuk melakukan pembelajaran dan pemberian tugas. Penggunaan media pembelajaran disesuaikan dengan kebutuhan pembelajaran agar pembelajaran daring berjalan efektif. Untuk melihat efektifitas pembelajaran daring dengan menggunakan media pembelajaran daring, peneliti melakukan survey kepada 27 tenaga pendidik. Terdapat empat kategori dalam angket yang peneliti sebarkan. Empat kategori itu adalah kategori kesiapan, kategori media pembelajaran, kategori tanggapan dan kategori kebermanfaatan.

Kita dapat melihat pada gambar pertama, yaitu persentase dari pernyataan pada kategori pertama. Pada gambar tersebut terdapat persentase dari setiap jawaban yang diberikan oleh tenaga pendidik. Gambar tersebut membuktikan bahwa 98\% tenaga pendidik memberikan respon positif, ini artinya bahwa sebagian besar tenaga pendidik sudah siap untuk melakukan pembelajaran daring walaupun pemerintah dan pihak-pihak terkait lainnya masih perlu untuk melakukan pelatihan pembelajaran daring kepada para tenaga pendidik. Tenaga pendidik perlu dipersiapkan agar mampu melakukan pembelajaran daring dan mengikuti setiap perkembangan teknologi pada dunia pendidikan.

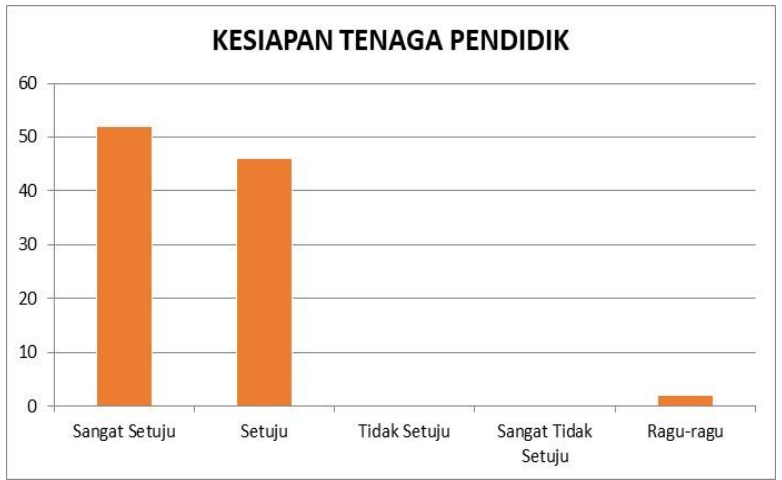

Gambar 1 : Kesiapan tenaga pendidik dalam melaksanakan pembelajaran daring

Pada gambar ke-2, hanya $42 \%$ tenaga pendidik yang menyatakan suka dengan penggunaan media pembelajaran daring, sementara 58\% lainnya menyatakan tidak suka dengan penggunaan media pembelajaran daring. Dapat kita lihat, meskipun data sebelumnya menunjukkan bahwa $98 \%$ tenaga pendidik siap dengan pelaksanaan pembelajaran daring, tetapi yang suka dengan penggunaan media daring ini tidak sampai $50 \%$. Hal ini disebabkan oleh beberapa faktor antara lain: tenaga pendidik yang belum terbiasa dengan pembelajaran daring, ketersediaan sarana maupun kuota yang digunakan saat pelaksanaan pembelajaran daring, hingga kondisi lingkungan yang kurang mendukung saat menggunakan media pembelajaran daring.

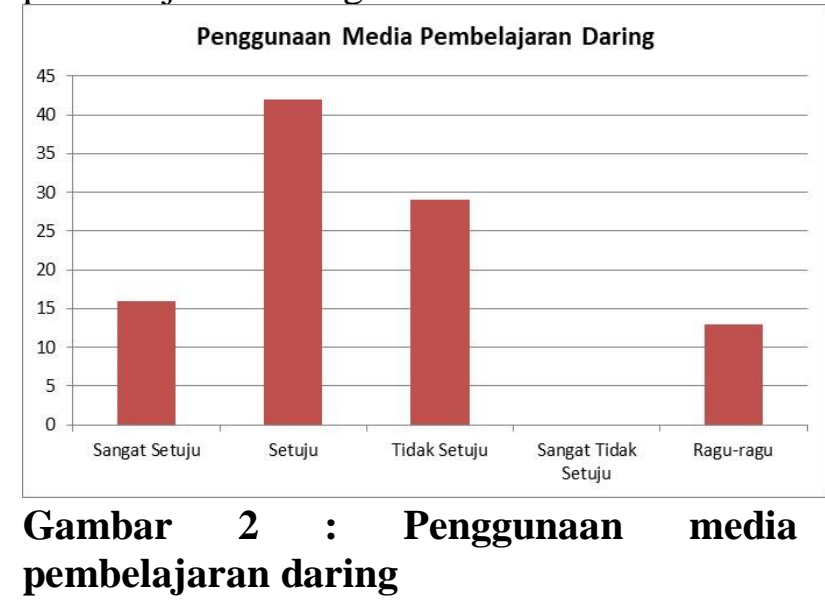

Berdasarkan gambar ke-3, persentase jawaban dari tenaga pendidik yang menunjukkan bahwa lebih banyak tenaga pendidik yang tidak setuju jika pembelajaran daring diterapkan di sekolah. Data menunjukkan bahwa hanya $18 \%$ tenaga 
pendidik yang memberikan tanggapan positif terkait penerapan pembelajaran daring. Media pembelajaran daring seharusnya bisa diterapkan di sekolah, akan tetapi diterapkan untuk waktu-waktu tertentu saja. Ini dilakukan agar peserta didik mendapatkan pengetahuan baru dan jika ada hal-hal yang terjadi di luar dugaan seperti mewabahnya virus corona ini tidak membuat peserta didik kaget. Hal ini juga dilakukan agar tenaga pendidik memiliki pengetahuan tentang media pembelajaran daring dan mengikuti perkembangan dalam dunia pendidikan.

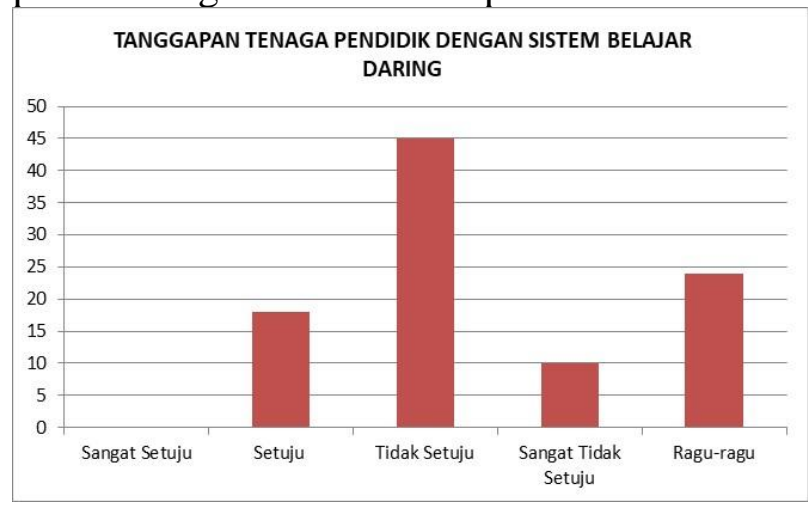

Gambar 3 : Tanggapan tenaga pendidik dengan sistem belajar daring

Hasil dari kategori ke-4 dapat kita lihat pada gambar ke-4, dimana secara spesifik menunjukkan persentase kebermanfaatan media pembelajaran daring khususnya dalam meningkatkan hasil belajar peserta didik. Ternyata data yang diperoleh menunjukkan bahwa hanya $24 \%$ tenaga pendidik yang memberikan respon positif terkait peningkatan hasil belajar peserta didik selama melaksanakan pembelajaran daring. Untuk sebagian tenaga pendidik, media pembelajaran daring sangatlah membantu dan untuk sebagian lagi ternyata belum cukup membantu untuk mentransfer ilmu dan meningkatkan hasil belajar peserta didik. Hal ini terjadi karena banyak tenaga pendidik yang tidak mengetahui cara menggunakan media pembelajaran daring karena pada sebelumnya mengajar secara tatap muka penuh di sekolah.

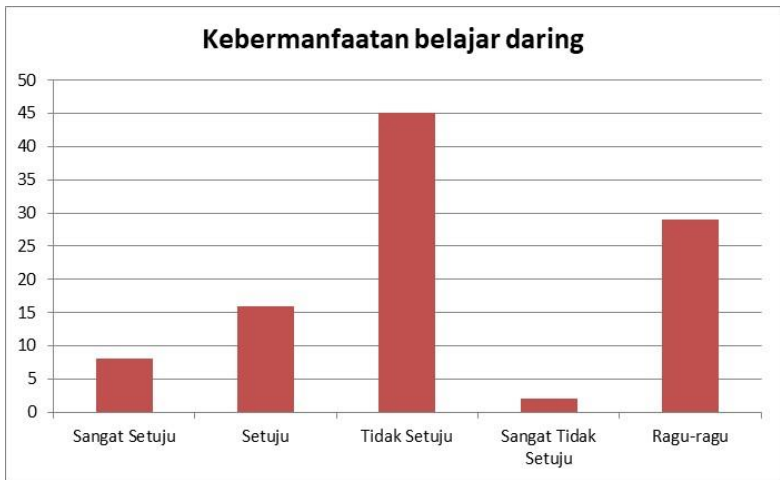

Gambar 4 : Kebermanfaatan belajar daring

Uraian dari ke-empat kategori mulai dari kesiapan, penggunaan media, tanggapan penerapan sistem pembelajaran daring hingga kebermanfaatannya, menunjukkan bahwa masih diperlukan usaha ekstra dari pemerintah dan berbagai pihak yang berkaitan agar tenaga pendidik dapat melaksanakan pembelajaran daring secara efektif. Tenaga pendidik perlu dibekali agar terbiasa menggunakan teknologi dalam proses pembelajaran. Selain itu, sarana dan prasarana untuk pelaksanaan pembelajaran daring ini juga perlu mendapat perhatian khusus dari pemerintah dan pihak terkait.

\section{KESIMPULAN}

Berdasarkan uraian hasil yang diperoleh dari jawaban tenaga pendidik dapat disimpulkan bahwa:

1. Kategori ke-1 (satu), $98 \%$ tenaga pendidik siap mengikuti perubahan dan mendukung arahan pemerintah untuk melaksanakan pembelajaran daring.

2. Kategori ke-2 (dua), $42 \%$ tenaga pendidik menunjukkan rasa suka dalam menggunakan media pembelajaran daring.

3. Kategori ke-3 (tiga), 18\% tenaga pendidik mendukung jika sistem pembelajaran daring ini diterapkan untuk waktu kedepan.

4. Kategori ke-4 (empat), hanya $24 \%$ tenaga pendidik yang menyatakan bahwa pembelajaran daring berjalan efektif dalam meningkatkan hasil belajar peserta didik.

Pembelajaran daring memiliki tantangan khusus, lokasi peserta didik dan tenaga pendidik yang terpisah saat pelaksanaan pembelajaran menyebabkan 
tenaga pendidik tidak dapat mengawasi secara langsung kegiatan peserta didik selama proses pembelajaran. Oleh karena itu disarankan pembelajaran daring sebaiknya diselenggarakan dalam waktu tidak lama mengingat peserta didik sulit mempertahankan konsentrasinya apabila pembelajaran daring dilaksanakan lebih dari satu jam.

Hasil penelitian juga melaporkan bahwa tidak sedikit peserta didik yang kesulitan dalam memahami materi pembelajaran yang diberikan secara daring. Bahan ajar biasa disampaikan dalam bentuk bacaan yang tidak mudah dipahami secara menyeluruh oleh peserta didik. Mereka berasumsi bahwa materi dan tugas tidak cukup karena perlu penjelasan secara langsung oleh tenaga pendidik.

Pembelajaran daring efektif untuk mengatasi pembelajaran yang memungkinan tenaga pendidik dan peserta didik berinteraksi dalam kelas virtual yang dapat diakses dimana saja dan kapan saja, namun, ada kelemahan, pembelajaran daring menyebabkan peserta didik tidak terawasi dengan baik selama proses pembelajaran. Lemah sinyal internet dan mahalnya biaya kuota menjadi tantangan tersendiri pembelajaran daring. Akan tetapi pembelajaran daring dapat menekan penyebaran Covid-19 di lingkungan SDN 9 Sila Kecamatan Bolo Kabupaten Bima.

\section{DAFTAR PUSTAKA}

Arzayeva, M., Rakhimzhanov, K., Abdrahmanova, A., \& Umitkaliev, U. (2015). Special aspects of distance learning in educational system. Anthropologist, 22(3), 449454.https://doi.org/10.1080/0972007 3.2015.1189190.

Caley, P., Philp, D. J., \& McCracken, K. (2008). Quantifying social distancing arising from pandemic influenza. Journal of the Royal Society Interface.

https://doi.org/10.1098/rsif.2007.119 7.
Darmalaksana, W. (2020). WhatsApp Kuliah Mobile . Fakultas Ushuluddin UINSunan Gunung Djati Bandung.

Firm an, F., \& Rahayu, S. (2020). Pembelajaran Online di Tengah Pandemi Covid-19. Indonesian Journal of Educational Science (IJES), 2(2), 81-89.

Garrison, D. R., \& Cleveland-Innes, M. (2005). in Online Learning : Interaction Is Not Enough.

Kuntarto, E. (2017). Keefektifan Model Pembelajaran Daring dalam Perkuliahan Bahasa Indonesia di Perguruan Tinggi. Indonesian Language Education and Literature, 3(1), 99-110.

Miles, M. B., \& Huberman, M. (1994). Qualitative Data Analysis Second Edition. SAGE Publications.

Molinda, M. (2005), Instructional Technology and Media for Learning New Jersey Colombus, Ohio.

Moore, J. L., Dickson-Deane, C., \& Galyen, K. (2011). E-Learning, online learning, and distance learning environments: Are they the same? Internet and Higher Education.

Nursobah, A., Dedih, U., Hapid, H., \& Nurhamzah, N. Dampak pembelajaran daring terhadap penguatan literasi informasi dalam budaya akademik mahasiswa.

Oknisih, N., \& Suyoto, S. (2019). PENGGUNAAN

APLEN (APLIKASI ONLINE) SEBAGAI UPAYA KEMANDIRIAN BELAJAR SISWA. In SEMINAR NASIONAL PENDIDIKAN DASAR (Vol. 1, No. 01).

Pangondian, R. A., Santosa, P. I., \& Nugroho, E. (2019). Faktor-Faktor Yang Mempengaruhi Kesuksesan Pembelajaran Daring Dalam Revolusi Industri 4.0. In Seminar Nasional Teknologi Komputer \& Sains (SAINTEKS) (Vol. 1, No. 1).

Rahadian, D. (2017). Teknologi informasi dan komunikasi (tik) dan kompetensi teknologi pembelajaran untuk 
pengajaran yang berkualitas. TEKNOLOGI PEMBELAJARAN, 2(1).

Sobron, A. N., \& Bayu, R. (2019). PERSEPSI SISWA

PENGARUH DARING LEARNING TERHADAP MINAT BELAJAR IPA. SCAFFOLDING:Jurnal Pendidikan Islam dan Multikulturalisme, 1(2), 30-38.

Sugiyono. (2013). Metode Penelitian Kuantitatif, Kualitatif dan R\&D. Bandung: Alfabeta.CV

WHO. (n.d.). Points of entry and mass gatherings. Retrieved March 28, 2020, from https://www.who.int/emergencies/dis eases/novelcoronavirus2019/technica lguidance/points-of-entry-and-massgatherings. 